\title{
Help Button for Elderly People on the Arduino Platform
}

\author{
Lázaro J. González Salgueiro / lazaro.gonzalez@upr.edu.cu
}

Ariosky Areces Gonzalez / ariosky@upr.edu.cu

Pablo A. Rueda Rodríguez / ale1995@upr.edu.cu

Universidad de Pinar del Río, Cuba

ABSTRACT The design and implementation of a system capable of providing elderly people with a fast track to ask for help, remotely, to the person in charge of their care, using the cellular network is reported t. The main functionality is a help button, through which the person in charge of the elderly care will receive a text message when the elder presses the button. Recognizing the little connection between the people of this age group with cellular technology, defining the number to which the messages will be sent (and writing them) is not their task. The system has other features of great value, as a group of automatic alarms, also operating via SMS, generated by a group of sensors included in the system, which facilitates remote decision making from caregivers.

KEYWORDS Elderly care; help button; Arduino; sensors.

Botón de ayuda para ancianos de la tercera edad sobre la plataforma Arduino

RESUMEN Se reporta el diseño e implementación de un sistema capaz de proveer a personas de la tercera edad de una vía rápida para pedir ayuda, de manera remota, al encargado de su cuidado, usando la red celular. Se implementó un sistema, cuya principal funcionalidad es un botón de ayuda, mediante el cual la persona encargada del cuidado del anciano recibirá un mensaje de texto cuando el anciano presione el botón. Reconociendo la poca vinculación de las personas de este grupo etario con la tecnología celular, definir el número al que se enviarán los mensajes (y escribirlos) es transparente para ellos. El sistema cuenta con otras prestaciones de gran valía, un grupo de alarmas automáticas, también vía SMS, definidas para un grupo de sensores incluidos en el sistema, que facilita la toma de decisiones de forma remota a través de un SMS.

PALABRAS CLAVE Guidado de ancianos; botón de ayuda; Arduino; sensores.
Botão de ajuda para idosos através da plataforma Arduino

RESUMO É relatado o desenho e a implementação de um sistema capaz de fornecer aos idosos uma via rápida para pedir ajuda, remotamente, à pessoa responsável pelos cuidados, usando a rede celular. Foi implementado um sistema, cuja principal funcionalidade é um botão de ajuda, através do qual a pessoa encarregada de cuidar dos idosos receberá uma mensagem de texto quando o idoso pressionar o botão. Reconhecendo a pouca conexão das pessoas desta faixa etária com a tecnologia celular, definir o número para o qual as mensagens serão enviadas (e a sua redação) é transparente para eles. $\mathrm{O}$ sistema possui outros recursos de grande valor, um grupo de alarmes automáticos, também via SMS, definidos para um grupo de sensores incluídos no sistema, o que facilita a tomada de decisões de forma remota através de um SMS.

PALAVRAS-CHAVE Guidado de idosos; botão de ajuda; Arduino; sensores. 


\section{Introduction}

Cuba is among the oldest nations in Latin America. It has 2,158,703 inhabitants aged 60 and over, representing $19.2 \%$ of its population, a figure that, according to experts, continues to increase in an accelerated way.

According to the priority that the Cuban State gives to the current problem of its accelerated population, the regular session of the National Assembly, took up the issue of supervision to repair, enlarge and equip elderly homes and grandparents' houses.

Hence, the State and health authorities design strategies and take actions to ensure that older people are healthier and enjoy a better life quality. Currently, the average survival in Cuba is 78.45 years (Fariñez, 2016).

The Universidad de Pinar del Río is involved in this process. So, in order to improve the life quality of the elderly, it has carried out some research aimed at automating some processes of their daily life. An example is this study, which pretends that the elderly, who are not familiar with the current technologies, can count on a system capable of, at any moment, sending a message to the person in charge of their care, just pressing a button.

\section{Materials and Methods}

As the main functionality, the proposed system responds to the need exposed, by interconnecting a button to the Arduino Uno programmable board on which a SIM900 GSM / GPRS Shield is already attached. This solution allows the person in charge of the elderly care to receive a previously defined SMS, once the elderly person presses the button, without having to write a text or define a number to send it. It should be noted that the process of defining the number to which the message needs to be sent is totally clear for the elderly.

In addition, the system is able to record several environmental parameters, such as temperature, humidity, and lighting, in order to improve the comfort of the elderly in the room. If any of these parameters are outside the defined range, an alert will also be automatically sent via SMS to the person in charge of caring for the elderly.

This system also allows the person in charge of the elderly care to know all the times and through via SMS, the behavior of each of the variables that are being sensed. After knowing these values, you can act on the equipment designed for the coupling of each of them, remotely, since a relay is used for the control of a higher-level power equipment.

\section{Introducción}

Como país, Cuba se ubica entre las naciones más envejecidas de América Latina, al tener 2.158.703 habitantes con 60 años y más, lo que representa el 19,2\% de su población, una cifra que, según los expertos, continuará incrementándose de manera acelerada.

A tono con la prioridad que el Estado cubano le otorga al envejecimiento acelerado de su población, el actual período ordinario de sesiones de la Asamblea Nacional, retomó el tema de la fiscalización a la reparación, ampliación y equipamiento de los hogares de ancianos y de las casas de abuelos.

De ahí que el Estado y las autoridades de la salud diseñen estrategias y realicen acciones para garantizar que las personas envejecidas sean más saludables y disfruten de mayor calidad de vida. Hoy el promedio de sobrevivencia en Cuba es de 78,45 años (Fariñez, 2016).

La Universidad de Pinar del Rio no está ajena a este proceso, por lo que, en aras de mejorar la calidad de vida de los ancianos, ha realizado algunas investigaciones encaminadas a automatizar algunos procesos de su vida cotidiana. Un ejemplo de ello es el presente trabajo, con el que se pretende que las personas de la tercera edad, quienes no están familiarizados con las tecnologías celulares actuales -y por tanto, se les hace muy engorroso utilizarlas-, puedan contar con un sistema capaz de, en cualquier momento, con solo presionar un botón enviarle un mensaje a la persona encargada de su cuidado.

\section{Materiales y método}

El sistema propuesto, como principal funcionalidad responde a la necesidad expuesta, mediante la interconexión de un botón a la placa programable Arduino Uno en el que ya está acoplado un shield GSM/GPRS SIM900. Esta solución permite que la persona encargada del cuidado del anciano pueda recibir un SMS previamente definido, una vez que el anciano presione el botón, sin necesidad de que tenga que escribir un texto o definir un número para enviarlo. Cabe aclarar que el proceso de definición del numero al que se desea enviar el mensaje es totalmente transparente para el anciano.

Además el sistema es capaz de censar varios parámetros ambientales, como la temperatura, la humedad y la iluminación, en aras de mejorar el confort del anciano en la habitación. Dado el caso de que alguno de estos parámetros esté por fuera del rango definido, también se le enviará, de forma automática, una alarma vía SMS a la persona encarga del cuidado del anciano.

Este sistema además, permite que la persona encargada del cuidado del anciano, en todo momento, pueda conocer, vía SMS, el comportamiento de cada una de las variables que se están censando. Y, dado el caso de que lo desee, después de conocer estos valores, puede actuar sobre los equipos destinados para el acople de cada una de ellas, de forma remota, ya que se utiliza un relay para el control de equipos de mayor potencia.

\section{A. Placa programable Arduino UNO}

La Arduino Uno (Figura 1) es una board basada en un microcontrolador Atmega328. Tiene catorce pines de entrada/ salida digital (de los cuales cuatro pueden ser utilizados para 
salidas PWM [Pulse Width Modulation]), seis entradas análogas, un resonador cerámico de $16 \mathrm{MHz}$, un conector para USB tipo hembra, un jack para fuente de poder, un conector ICSP [In Circuit Serial Programming] y un botón de reset (Guerrero, 2014).

La placa tiene todo lo necesario para manejar el controlador (ver Figura 2), simplemente se conecta al computador por medio del cable USB o a una fuente de poder externa, que puede ser un adaptador AC-DC [Alternating Current - Direct Current] o una batería. Cabe aclarar que, si se alimenta a través del cable USB en el ordenador, no es necesario que se conecte a una fuente externa.

Para programar la board se necesita el IDE Arduino. Sus características son:

- Microcontrolador: ATmega328.

- Voltaje operativo: 5v.

- Voltaje de entrada (recomendado): $7-12 \mathrm{v}$.

- Pines de entrada/salida digital: 14 (de ellas, seis son salidas PWM).

- Pines de entradas análogas: 6 .

- Memoria flash: $32 \mathrm{~KB}$ (ATmega328) de ellos 0,5 KB usados por boot-loader.

- SRAM: 2 KB (ATmega328).

- EEPRO: 1 KB (ATmega328).

- Velocidad del reloj: 16 MHZ.

Arduino es una plataforma de hardware y software libre, por lo que es posible obtener su esquemático y su diseño, además posee unas librerías bastante enriquecidas gracias a que su comunidad de programadores es cada día mayor.

\section{B. Shield GSM/GPRS SIM900}

GPRS/GSM shield SIM900 (Figuras 3, 4 y 5) es un escudo ultra compacto y confiable basado en el chip SIM900, 100\% compatible con Arduino Uno y Mega. Puede trabajar en frecuencias GPRS/GSM de 850/900/1800/1900 MHz, para realizar llamadas de voz, envío de SMS y fax. Tiene muy bajo consumo de energía y un diseño muy pequeño con grandes posibilidades.

Se controla y configura mediante un protocolo UART [Universal Asynchronous Receiver-Transmitter], usando comandos

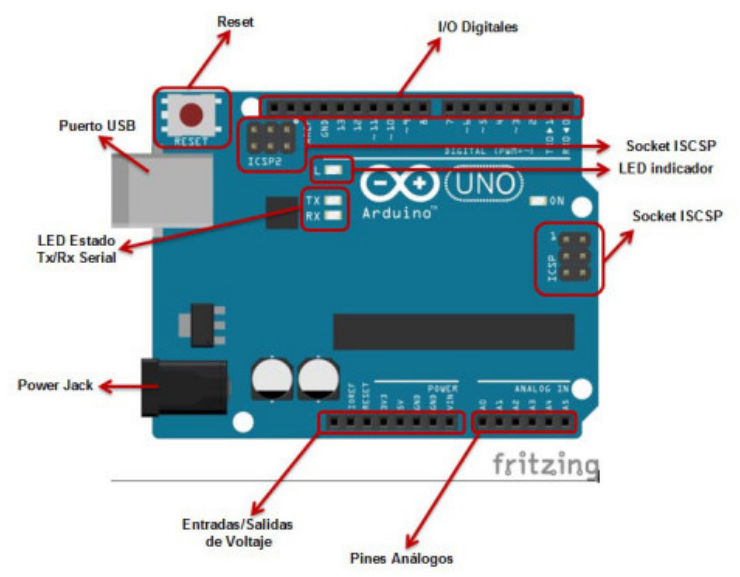

Figure 2. Arduino Uno components / Partes del Arduino Uno

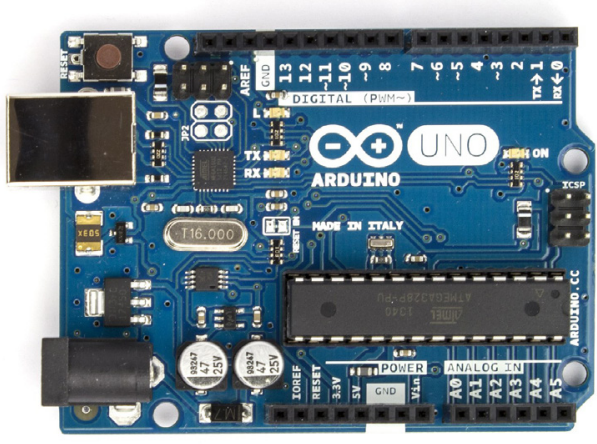

Figure 1. Arduino Uno front view / Vista frontal del Arduino Uno

\section{A. Arduino UNO programable board}

The Arduino Uno (FIgure 1) is a board based on an Atmega328 microcontroller. It has fourteen digital input / output pins (which four can be used for PWM [Pulse Width Modulation] outputs), six analog inputs, a $16 \mathrm{MHz}$ ceramic resonator, a USB type female connector, a jack for power source, an ICSP [In Circuit Serial Programming] connector and a reset button (Guerrero, 2014).

The board has everything necessary to operate the controller (FIGURE 2), it is simply connected to the computer through the USB cable or an external power source, which can be an AC-DG adapter [Alternating Current - Direct Current] or a battery. It should be noted that, if it is powered through the PC USB, it is not necessary to connect to an external source. To program the board you need the Arduino IDE.

Their characteristics are:

- Microcontroller: ATmega328.

- Operating voltage: $5 \mathrm{v}$.

- Input voltage (recommended): 7 - $12 \mathrm{v}$.

- Digital input / output pins: 14 (of which six are PWM outputs).

- Analog Input Pins: 6.

- Flash memory: $32 \mathrm{~KB}$ (ATmega328) of them 0.5 $\mathrm{KB}$ used by boot-loader.

- SRAM: 2 KB (ATmega328).

- EEPRO: 1 KB (ATmega328).

- Clock speed: 16 MHZ.

Arduino is a platform for free hardware and software. Therefore, it is possible to obtain its schematics and its design, and it also has some libraries that are quite enriched thanks to the fact that its community of programmers is growing. 

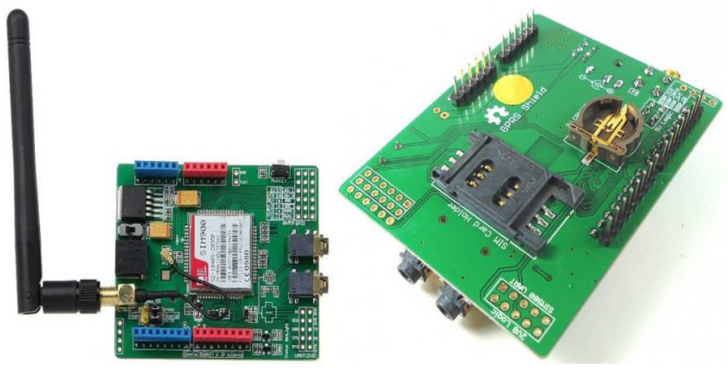

Figure 3. Shield GSM/GPRS SIM900 / Placa GSM/GPRS SIM900

\section{B. SIM900 GSM / GPRS Shield}

SIM900 GSM / GPRS (Figure 3, 4 and 5) is an ultra-compact and reliable shield based on the SIM900 chip, 100\% compatible with Arduino Uno and Mega. It can work on 850/900/1800/1900 MHz GPRS / GSM frequencies, to make voice calls, send SMS and fax. It has very low power consumption and a very small design with great possibilities.

It is controlled and configured through a UART protocol (Universal Asynchronous Receiver-Transmitter), using AT commands. By default, the UART speed is set to 19200 baud. For this function it has a jumper, in order to select the digital pins through which communication is wanted (D0-D3); on the board there is a switch that allows to select between a UART connection or a debug port, which can be configured for the Arduino as well. The SIM900 can be connected directly to a PC through an FTDI232 chip. One of the most interesting functions is that it has a super capacitor with its own power circuit, which can operate as a RTC and give information about the date and time (PatagoniaTec, 2017).

Their characteristics are:

- fully compatible with Arduino Connection, with serial port;

- Quad-Band 850/900/1800/1900 MHz;

- GPRS multi-slot class 10 / 8GPRS mobile station class B;

- compatible GSM phase 2/2 + Class 4 (2 W (AT) 850/900 MHz);

- Class 1 (1 W (AT) 1800 / 1900MHz) Embedded TCP / UP; and

- supports RTC, consumption of $1.5 \mathrm{~mA}$ (susp).

The SIM900 card model that was used does not include the pins to set it up directly on the Arduino, but it will

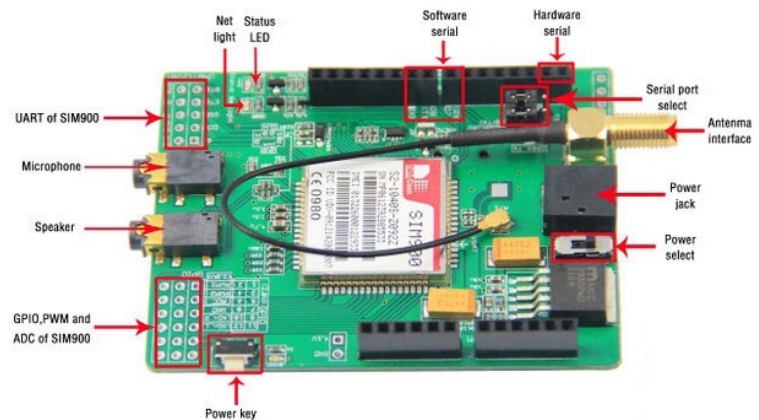

Figure 4. Components of the Shield GSM/GPRS SIM900 / Placa GSM/GPRS SIM900 y sus partes

AT. Por defecto, la velocidad UART está configurada en 19200 baudios. Para esta función posee un jumper, para poder seleccionar los pines digitales mediante los que se quiere realizar la comunicación (D0-D3); en la placa hay un switch que permite seleccionar entre una conexión UART o un puerto de debug, que se puede configurar para el Arduino también. El SIM900 se puede conectar directamente a una PG a través de un chip FTDI232. Una de las funciones más interesantes es que posee un súper capacitor con su propio circuito de alimentación, capaz de funcionar como RTG y dar información de la fecha y hora (PatagoniaTec, 2017).

Sus características son:

- Totalmente compatible con Arduino Conexión, con el puerto serial.

- Quad-Band 850/ 900/ 1800/ 1900 MHz.

- GPRS multi-slot clase 10/8GPRS mobile station clase B.

- Compatible GSM fase 2/2+Clase 4 (2 W (AT) 850 / $900 \mathrm{MHz})$.

- Clase 1 (1 W (AT) 1800 / 1900MHz)TCP/UP embebido.

- Soporta RTC, consumo de $1.5 \mathrm{~mA}$ (susp).

El modelo de tarjeta SIM900 que se utilizó no incluye los pines para montarlo directamente sobre el Arduino, pero no causará problemas en la conexión ya que es controlado por UART, solo se necesita TX y RX.

Para la transmisión de datos entre el SIM900 y el Arduino se utilizan los pines 7 y 8, así que, es necesario asegurar que los jumper de la tarjeta GSM están posicionados en D7 y D8, para activar estos pines (HeTPro, 2017).

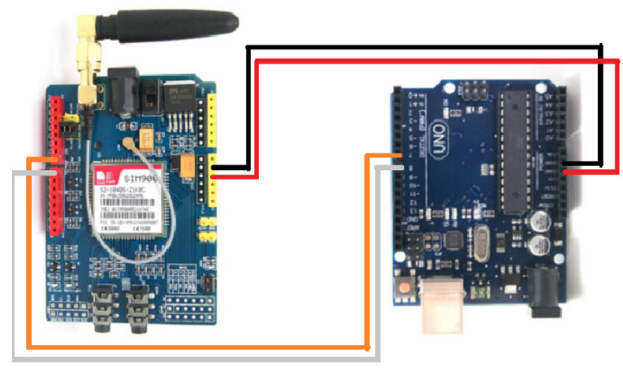

Figure 5. GSM/GPRS SIM900 Shield connection with Arduino UNO / Conexión del Shield GSM/GPRS SIM900 con el Arduino UNO 


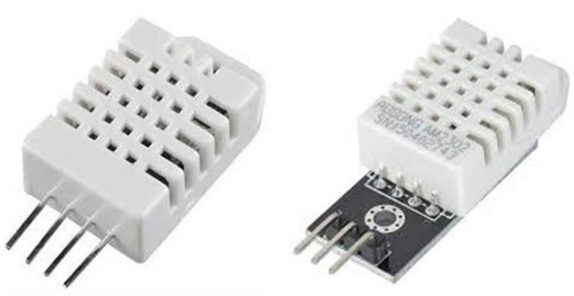

Figure 6. Several commercial DHT22 Sensors / Modelos comerciales del sensor DHT22

C. Sensores

Sensor de temperatura y humedad DHT22

El sensor DHT22 (FIGURA 6) nace como una evolución natural del DHT11, con mayores rangos de temperatura y humedad, y más precisión.

El sensor se puede encontrar suelto, con una "funda" blanca plástica y cuatro pines de conexión, o con la misma funda blanca, pero soldado en una placa y con tres pines de conexión, además de una resistencia pull-up (entre 3-6 k $\Omega$ ) y un condensador de filtrado, normalmente de $100 \mathrm{nF}$ (Llamas, 2016A; García, 2014).

Sus principales características son:

- Alimentación: $3.3 \mathrm{v}-5.5 \mathrm{v}$, tomando como valor recomendado $5 \mathrm{v}$.

- Resolución decimal, es decir que los valores, tanto para humedad, como para temperatura, son números con una cifra decimal.

- Tiempo de muestreo: 2 segundos, es decir, sólo puede ofrecer datos cada 2 segundos.

En cuanto a sus prestaciones leyendo temperatura:

- Rango de valores: desde $-40^{\circ} \mathrm{C}$ hasta $80^{\circ} \mathrm{C}$.

- Precisión: $\pm 0.5^{\circ} \mathrm{C}, \pm 1^{\circ} \mathrm{C}$, como máximo en condiciones adversas.

- Tiempo de respuesta: <10 segundos, es decir, de media, tarda menos de 10 segundos en reflejar un cambio de temperatura real en el entorno.

Y sus prestaciones leyendo humedad relativa:

- Rango: desde 0 \% hasta $99.9 \%$.

- Precisión: $\pm 2 \%$ RH, a una temperatura de $25^{\circ} \mathrm{C}$.

- Tiempo de respuesta: <5 segundos, es decir, de media, tarda menos de cinco segundos en reflejar un cambio de humedad relativa real en el entorno (para esta afirmación la velocidad del aire, de acuerdo con los test, debe ser de $1 \mathrm{~m} / \mathrm{s}$ ).

\section{Sensor de llamas}

Un sensor de llama óptico es un dispositivo que permite detectar la existencia de combustión a partir de la luz emitida por la misma. Esta luz puede ser detectada por un sensor óptico y ser capturada por las entradas digitales y las entradas analógicas de Arduino. Algunos sensores comerciales de este tipo se presentan en la Figura 7.

La llama es un fenómeno de emisión de luz asociado a los procesos de combustión. La combustión es un proceso que not cause connection problems since it is controlled by UART. Only TX and RX are needed.

For the data transmission between the SIM900 and the Arduino, pins 7 and 8 are used, so it is necessary to ensure that the jumpers of the GSM card are positioned in D7 and D8 to activate these pins (HeTPro, 2017).

\section{Sensors}

\section{DHT22 temperature and humidity sensor}

The DHT22 sensor (FIgURE 6) is created as a natural evolution of DHT11, with higher temperature and humidity ranges, and more accuracy.

The sensor can be found loose, with a white plastic "case" and four connection pins, or with the same white sleeve, but welded on a plate and with three connection pins, as well as a pull-up resistor (between 3- $6 \mathrm{k} \Omega$ ) and a filtering capacitor, normally $100 \mathrm{nF}$ (Llamas, 2016A, García, 2014).

Its main characteristics are:

- Power source: $3.3 \mathrm{v}-5.5 \mathrm{v}$, tomando como valor recomendado $5 \mathrm{v}$.

- Power source: $3.3 \mathrm{v}-5.5 \mathrm{v}$, taking $5 \mathrm{v}$ as recommended value.

- Decimal resolution. Humidity and temperature values are numbers with a decimal number.

- Sampling time: 2 seconds, that is, it can only offer data every 2 seconds.

Regarding its benefits, reading temperature:

- Range of values: from $-40^{\circ} \mathrm{C}$ to $80^{\circ} \mathrm{C}$.

- Accuracy: $\pm 0.5^{\circ} \mathrm{C}, \pm 1^{\circ} \mathrm{C}$, maximum in adverse conditions.

- Response time: $<10$ seconds, that is, on average, it takes less than 10 seconds to reflect a real temperature change in the environment.

And its benefits, reading relative humidity:

- Range: from $0 \%$ to $99.9 \%$.

- Accuracy: $\pm 2 \% \mathrm{RH}$, at a temperature of $25^{\circ} \mathrm{C}$.

- Response time: $<5$ seconds, that is, on average, it takes less than five seconds to remark a change of real relative humidity in the environment (according to the tests, the air speed must be of $1 \mathrm{~m} / \mathrm{s}$ for this affirmation).

\section{Flame sensor}

An optical flame sensor is a device that detects the existence of combustion from the light emitted by this one. 
This light can be detected by an optical sensor and captured by the digital inputs and analog inputs of Arduino. Some commercial flame sensors for Arduino are shown

\section{in Figure 7.}

The flame is a phenomenon of light emission associated with combustion processes. Combustion is a process that releases large amounts of energy in a heat form. During the reaction, intermediate compounds are generated that release part of their energy through the emission of light.

The spectrum of flame emission depends on the elements that intervene in the reaction. In the case products combustion with carbon in the presence of oxygen, two characteristic peaks are presented in ultraviolet, in $185 \mathrm{~nm}-260 \mathrm{~nm}$ wavelengths, and in infrared, in 4400$4600 \mathrm{~nm}$ wavelengths (Llamas, 2016B).

Flame sensors are widely used in the industry. Many machines execute processes that are liable to generate flames, such as, for example, machining or electro-erosion processes. Frequently they are carried out in the presence of combustible elements, such as oil or shavings.

Flame sensors are incorporated as safety devices that allow stopping the process in case of detecting any sign of combustion. These devices adjust to the wavelengths characteristic of the flame appearance and usually combine ultraviolet and infrared signals.

The electrical diagram is simple, the module is powered by connecting GND and $5 \mathrm{~V}$ to the corresponding Arduino pins. Now, if you want to use digital reading, you can connect the DO output to one of the Arduino digital inputs; if you want to use the analog value, simply connect the $\mathrm{AO}$ output of the sensor to an analog input of Arduino (Prometec, 2016).

\section{Magnetic sensor for windows and doors}

The magnetic sensor for windows and doors (Figure 8) consists of a magnet and a reed switch (magnetic switch). This sensor works like a normally open switch (while there is a magnetic field). When the door or window is opened, the electrical circuit closes and it is possible to detect the respective opening. The sensor comes completely sealed in plastic which makes it extremely resistant ("Sensor ...", 2017).

The connection with other systems is made by cables that are previously installed in the sensor and that will have to be connected with a longer cable. The assembly on the door or window can be done

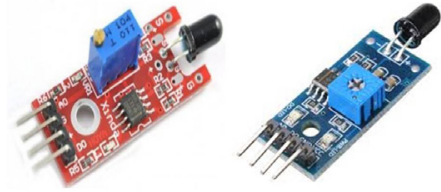

Figure 7. Commercial fire sensors for Arduino / Sensores de llamas comerciales para Arduino

desprende grandes cantidades de energía en forma de calor. Durante la reacción se generan compuestos intermedios que liberan parte de su energía mediante la emisión de luz.

El espectro de emisión de llama depende de los elementos que intervienen en la reacción. En el caso de la combustión de productos con carbón en presencia del oxígeno, se presentan dos picos característicos en ultravioleta, en longitudes de onda de $185 \mathrm{~nm}-260 \mathrm{~nm}$, y en infrarrojo, en longitudes de onda 44004600nm (Llamas, 2016B).

Los sensores de llama son ampliamente utilizados en la industria. Muchas máquinas ejecutan procesos susceptibles de generar llamas, como por ejemplo, los procesos de mecanizado o de electroerosión. Frecuentemente se realizan en presencia de elementos combustibles, como el aceite o la viruta.

Se incorporan sensores de llama como dispositivos de seguridad que permiten detener el proceso en caso de detectar cualquier indicio de combustión. Estos dispositivos se ajustan a las longitudes de onda características de la aparición de la llama y normalmente combinan las señales ultravioleta e infrarroja.

El esquema eléctrico es sencillo, se alimenta el módulo conectando GND y $5 \mathrm{~V}$ a los pines correspondientes de Arduino. Aho$\mathrm{ra}$, si se quiere usar la lectura digital, se conecta la salida DO a una de las entradas digitales de Arduino; si se quisiera emplear el valor analógico, simplemente se conecta la salida $\mathrm{AO}$ del sensor a una entrada analógica de Arduino (Prometec, 2016).

\section{Sensor magnético para ventanas y puertas}

El sensor magnético para ventanas y puertas (FIGURA 8) consta de un imán y un reed switch (interruptor magnético). Este sensor funciona como un switch normalmente abierto (mientras hay campo magnético). Cuando la puerta o ventana se abre, el circuito eléctrico se cierra y es posible detectar la respectiva apertura. El sensor viene completamente sellado en plástico lo que lo hace extremadamente resistente ("Sensor...", 2017).

La conexión con otros sistemas se realiza mediante cables que vienen previamente instalados en el sensor y que habrá que unir con un cable más largo. El montaje en la puerta o ventana puede realizarse mediante cinta autoadherible (viene incluida) o mediante tornillos, si se desea una mejor fijación.

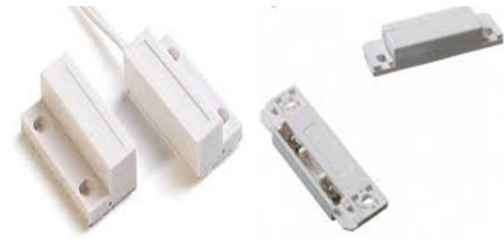

Figure 8. Commercial magnetic sensors for windows and doors /modelos comerciales de sensores magnéticos para ventanas y puertas 


\section{Resultados}

La implementación del sistema, teniendo en cuenta las características y la interconexión de cada uno de los componentes descritos con el Arduino UNO, se muestra en la Figura 9.

Además del botón de ayuda, su principal funcionalidad, el sistema cuenta con otras prestaciones de gran valía, como es el caso de un grupo de alarmas, también vía SMS, totalmente automáticas, que atiende a cada uno de los valores de umbrales que le sean definidos para cada uno de los sensores que se utilizan en el sistema:

- cuando la temperatura supera los $32^{\circ} \mathrm{C}$ o es menor de $20^{\circ} \mathrm{C}$;

- cuando la humedad relativa sale del rango entre 40 y $60 \%$;

- cuando se abre alguna de las puertas o ventanas;

- cuando la luz de la habitación cambia su estado; y

- cuando se detecta algún tipo de componente infrarroja, principalmente fuego.

Usando la red celular, a través de un mensaje de texto, se puede conocer el estado de cada una de estas variables, en cualquier momento:

- consultar el valor de temperatura y humedad;

- consultar el estado de las puertas y ventanas; y

- saber si la luz está encendida o apagada.

El sistema también facilita la toma de decisiones a través de un mensaje de texto:

- si la temperatura o la humedad no están en el valor deseado, se puede enviar un SMS para encender el equipo que puede incidir en estos parámetros; y

- se puede variar el estado de luz, para poder incidir sobre el parámetro de iluminación.

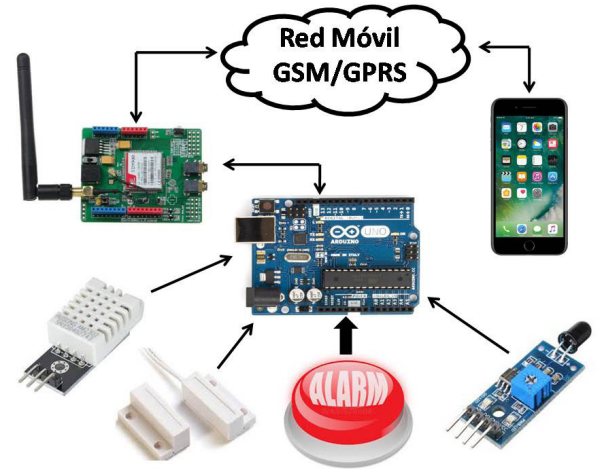

Figure 9. Final implementation / Implementación final del sistema

\section{Conclusiones}

Con la implementación de este sistema destinado a la ayuda de ancianos de la tercera edad, se obtiene un prototipo bastante completo y totalmente funcional para su puesta en práctica, tanto por cualquier persona que necesite mantener el control de los parámetros de la habitación donde se encuentra un anciano que este bajo su cuidado y que este pueda contar con una vía para pedir ayuda lo más sencilla posible, como en cualquier hogar de ancianos o casa de abuelos, teniendo en cuenta que en esta variante se pudiera cambiar la plataforma de comunicación por una más económica como Wi-Fi. $\mathbf{S T}$ with self-adhesive tape (included) or with screws for a better attachment.

\section{Results}

The implementation of the system, taking into account the characteristics and the interconnection of each of the components described with the Arduino UNO, is shown in Figure 9.

Besides the help button, its main functionality, the system has other great benefits. In the case of a group of alarms, also via SMS, fully automatic, which attends each of the thresholds values that are defined for each of the sensors used in the system:

- When the temperature exceeds $32^{\circ} \mathrm{C}$ and or decreases from $20^{\circ} \mathrm{C}$;

- when the relative humidity goes out of the range between 40 and 60 percent;

- when any of the doors or windows are opened;

- when the light of the room changes its state; and

- when some type of infrared component is detected, mainly fire.

Using the cellular network, through a text message, you can know the status of each of these variables, at any time:

- Check the temperature and humidity value;

- check the status of doors and windows; and

- know if the light is on or off.

The system also facilitates decision making through a text message:

- If the temperature or humidity are not at the desired value, an SMS can be sent to turn on the equipment that can affect these parameters; and

- the light status can be modified, in order to influence the lighting parameter.

\section{Conclusions}

The implementation of this system aimed at helping elderly people provides a fairly complete and fully functional prototype is obtained for its execution, by any person who needs to maintain control of the room parameters where there is an elderly person under his care and who can have a way to ask for help as simple as possible, including any home for the elderly or grandparents, taking into account that in this variant could change the platform of communication for a more economical one like Wi-Fi. St 


\section{References / Referencias}

Fariñez, G. (2016, July 8). Envejecimiento poblacional en Cuba: prioridad parlamentaria. Revista Mujeres. Retrieved from: http://www.mujeres.co.cu/art.php?MjQ3NA==

García, A. (2014, Feb. 8). DHT22: Sensor de humedad/temperatura de precisión para Arduino. Retrieved from: http://panamahitek.com/dht22-sensor-de-humedadtemperatura-de-precision-para-arduino/

Guerrero, J. (2014, Sept. 21). Arduino Uno: especificaciones y características. Retrieved from: http://arduino.cc

HeTPro. (2017, Sept.). SIM900 GSM GPRS shield con arduino uno. Retrieved from: http://www.instructables.com/id/SIM900GSM-GPRS-SHIELD-CON-ARDUINO-UNO/

Llamas, L. (2016a, July 1). Detector de Ilama con Arduino y sensor infrarrojo. Retrieved from: https://www.luisllamas.es/ detector-Ilama-arduino/

Llamas, L. (2016b, March 29). Medir temperatura y humedad con Arduino y sensor DHT11-DHT22. Retrieved from: https:// www.luisllamas.es/arduino-dht11-dht22/

PatagoniaTec. (2017, Nov.). GPRS/GSM Shield SIM900. Retrieved from: http://saber.patagoniatec.com/ gprsgsm-shield-sim900-arduino-argentina-ptec-elecfreaks/

Prometec. (diciembre de 2016). Detector de llama: Arduino y los sensores de fuego. Retrieved from: https://www.prometec. net/detector-llama/\#

Sensor magnético para ventanas y puertas (2017). Retrieved from: https://www.geekfactory.mx/tienda/sensores/sensor-magnetico-para-ventanas-y-puertas/ 


\section{CURRICULUM VITAE}

Lázaro J. González Salgueiro. Engineer in Telecommunications and Electronics from the Universidad de Pinar del Río "Hermanos Saiz Montes de Oca" [UPR] (Cuba, 2016). Professor of the Department of Telecommunications and Electronics of the Faculty of Technical Sciences of the UPR since 2016. He has taught the subjects of telephone switching and IP telephony. He has researched about voice synthesis and broadband encoders. She researches in the areas of: process automation, help systems and early warning for the elderly, and implementation of VolP telephone exchanges with Raspberry_Pi / Ingeniero en Telecomunicaciones y Electrónica de la Universidad de Pinar del Río "Hermanos Saiz Montes de Oca" [UPR] (Cuba, 2016). Profesor del Departamento de Telecomunicaciones y Electrónica de la Facultad de Ciencias Técnicas de la UPR desde 2016. Ha impartido las asignaturas de Conmutación Telefónica y Telefonía IP. Ha indagado en temáticas como la síntesis de voz y los codificadores de banda ancha. Investiga en las áreas de: automatización de procesos, sistemas de ayuda y alerta temprana para ancianos de la tercera edad, e implementación de centrales telefónicas VolP con Raspberry_Pi.

Ariosky Areces González Computer Science Engineer from Universidad de Ciencias Informáticas (Cuba, 2008); Specialist B in Computer Science in the Computerization Department of the UCI (2008-2014); Specialist $\mathrm{B}$ in Computer Science in the Department of Computing belonging to the Provincial Directorate of Sports in Pinar del Río (Cuba); Instructor Professor of the Computer Department of the Universidad de Pinar del Río "Hermanos Saiz Montes de Oca" (Cuba), since 2016. His areas of professional interest include: administration of servers in cloud; development of web applications in Symphony, Laravel and Java; development of documentary and archival management systems in Alfresco; and development of Android applications for mobile devices / Ingeniero en Ciencias Informáticas, graduado en Universidad de las Ciencias Informáticas [UCI] (Cuba, 2008); Especialista B en Ciencias Informáticas en la Dirección de Informatización de la UCI (2008-2014); Especialista B en Informática en el Departamento de Informática perteneciente a la Dirección Provincial de Deportes en Pinar del Río (Cuba); profesor Instructor del Departamento de Informática de la Universidad de Pinar del Río "Hermanos Saiz Montes de Oca" (desde 2016). Sus áreas de interés profesional incluyen: administración de servidores en la nube; desarrollo de aplicaciones web en Symphony, Laravel y Java; desarrollo de sistemas de gestión documental y archivística en Alfresco; y desarrollo de aplicaciones Android para dispositivos móviles.

Pablo Alejandro Rueda Rodríguez Technical in Computing (2013). He works as a computer technician at the Universidad de Pinar del Río "Hermanos Saiz Montes de Oca" [UPR] (Cuba), where he is also a student of third year of Telecommunications. His areas of interest are: development of applications with the $\mathrm{C}++$, web programming, programming for mobile devices and developing of automated systems using Arduino and Raspberry Pi platforms / Técnico Medio en Informática (2013). Se desempeña como técnico informático en la Universidad de Pinar del Río "Hermanos Saiz Montes de Oca" [UPR], donde es estudiante de tercer año de Telecomunicaciones. Sus áreas de interés son: el desarrollo de aplicaciones con lenguaje de programación $\mathrm{C}++$, la programación web, la programación para dispositivos móviles y el desarrollo de sistemas automatizados mediante las plataformas Arduino y Raspberry Pi. 